\title{
Retrograde fluorogold labeling of retinal ganglion cells in neonatal mice
}

\author{
Huiling Hu ${ }^{1 \#}$, Ying Liu ${ }^{2 \#}$, Kang Li ${ }^{2}$, Min Fang ${ }^{1}$, Yunyun Zou ${ }^{1}$, Jiantao Wang ${ }^{1}$, Jian Ge ${ }^{2}$ \\ ${ }^{1}$ Shenzhen Eye Hospital, Shenzhen Eye Hospital Affiliated to Jinan University, School of Optometry, Shenzhen University, Shenzhen, China; ${ }^{2}$ State \\ Key Laboratory of Ophthalmology, Guangdong Provincial Key Laboratory of Ophthalmology and Visual Science, Zhongshan Ophthalmic Center, \\ Sun Yat-sen University, Guangzhou, China \\ Contributions: (I) Conception and design: H Hu, Y Liu; (II) Administrative support: J Wang, J Ge; (III) Provision of study materials or patients: J \\ Wang, J Ge; (IV) Collection and assembly of data: K Li, Y Zou; (V) Data analysis and interpretation: M Fang; (VI) Manuscript writing: All authors; \\ (VII) Final approval of manuscript: All authors. \\ \#These authors contributed equally to this work. \\ Correspondence to: Jiantao Wang. Shenzhen Eye Hospital, 18\#Zetian Road, Shenzhen 518000, China. Email: wangjiantao65@126.com; Jian Ge. \\ Zhongshan Ophthalmic Center, 54\# Xianlienan Road, Guangzhou 510060, China. Email: gejian@mail.sysu.edu.cn.
}

Background: The neonatal period, especially postnatal day 10 (P10), is important for mouse retinal ganglion cells (RGCs) development, and an effective labeling technique to track neonatal RGCs is needed. Retrograde fluorogold (FG) labeling is widely used for adult mouse RGCs, but its applicability for the neonatal mouse is still unknown. This study aimed to evaluate the safety and efficiency of retrograde FG labeling in P10 mice.

Methods: The anatomic location of the superior colliculus (SC) of P10 wild-type C57/BL6J mice was clarified by histological brain section and hematoxylin and eosin (H\&E) staining. Three doses of $3 \%$ FG were injected into the SC of 30 mice, and 3 days post-surgery, labeling efficiency was quantified by retinal flat-mounts, and labeling safety was evaluated by mice mortality.

Results: Samples of brain tissue from 2-3.5 mm posterior to the bregma, and from 0.5-2.0 mm lateral to the midline showed major SC-related structures. The FG-positive RGC density in the $0.3 \mu \mathrm{L}$ group was $3,563.9 \pm 311.9$ cells $/ \mathrm{mm}^{2}$, significantly more than in the $0.6 \mu \mathrm{L}$ group $\left(1,718.6 \pm 177.1 \mathrm{cells} / \mathrm{mm}^{2}\right)$ or $1.0 \mu \mathrm{L}$ group $\left(2,496.8 \pm 342.2\right.$ cells $\left./ \mathrm{mm}^{2}\right)$. The mortality rate was $10 \%$ in both the 0.3 and $0.6 \mu \mathrm{L}$ groups, but $40 \%$ in the $1.0 \mu \mathrm{L}$ group.

Conclusions: The appropriate labeling site in P10 mice was confirmed and $0.3 \mu \mathrm{L}$ FG is an appropriate dose for retrograde labeling of RGCs.

Keywords: Retrograde trace;-retinal ganglion cell (RGC); ·superior colliculus (SC);-neonate

Submitted Mar 31, 2021. Accepted for publication May 17, 2021.

doi: 10.21037/atm-21-2022

View this article at: http://dx.doi.org/10.21037/atm-21-2022

\section{Introduction}

The neonatal period is important for retinal development in the mouse, during which time many retina precursor cells exit from mitosis and develop into mature retinal neurons. For retinal ganglion cells (RGCs), specifically, postnatal day $10(\mathrm{P} 10)$ is quite critical: it is the end stage of RGCs developmental culling process (1); it is the time when the retinal neurotransmitter gamma-aminobutyric acid's immune reactivity starts to effect RGCs (2); and it is the beginning of the process of eliminating topographic targeting errors of RGCs (3). These processes indicate the variability of RGCs at P10 and an appropriate RGC labeling technique is needed for effective tracking of the cells.

Retrograde fluorogold (FG) labeling is a well-known 
method of tracking adult RGCs in animal research (4-8), with regard to RGC development, survival and regeneration (9-12). FG is a widely used neuronal tracer that shows persistent RGC labeling. It travels from the superior colliculus (SC) to the RGC soma in rodents within 1 week and persists for several weeks, enabling reliable quantification of RGC density (11). However, there is no evidence that retrograde FG labeling is applicable in neonatal mice, especially P10 mice.

Therefore, the present study was designed to investigate the applicability of retrograde FG for labeling RGCs on P10 mice, including the most suitable injection site and dose of FG.

We present the following article in accordance with the ARRIVE reporting checklist (available at http://dx.doi. org/10.21037/atm-21-2022).

\section{Methods}

\section{Animals and materials}

All animal studies were conducted according to the Association for Research in Vision and Ophthalmology (ARVO) Statement for the care and use of animals and approved by the Animal Ethics Committee of Zhongshan Ophthalmic Center, Sun Yat-sen University. Pregnant C57/ BL6 mice were provided by the Laboratory Animal Center of the Sun Yat-sen University (Guangzhou, China). Mice were kept on a 12-h light/dark cycle with standard diet provided by the Laboratory Animal Center of Zhongshan Ophthalmic Center. All experiments were performed on P10 mice of either sex. Pups were returned to their dams after FG labeling.

FG and phosphate-buffered saline (PBS) were obtained from Invitrogen (Carlsbad, CA, USA). 26G and 30G microneedles were purchased from Becton, Dickinson and Company (Franklin Lakes, NJ, USA). All other materials were from Sigma Chemical Corporation (St. Louis, MO, USA), unless otherwise indicated.

\section{Mouse brain bistology}

Two P10 mice were killed by overdose of an anesthesia cocktail (100 mg/kg ketamine $+20 \mathrm{mg} / \mathrm{kg}$ xylazine) followed by heart perfusion of $5 \mathrm{~mL}$ ice-cold PBS and finally $5 \mathrm{~mL}$ of $4 \%$ paraformaldehyde in PBS. The skin along the midline between ears was incised, the skull was punctured through the bregma toward the brain with a $30 \mathrm{G}$ needle to locate the point on the brain under the bregma. The brain was gently dissected free from the skull and placed dorsal surface up in a $35-\mathrm{mm}$ petri dish on ice. Coronal plane and sagittal plane specimens were respectively obtained from three mice brains. Specifically, four coronal specimens were taken from 2.0 to $3.5 \mathrm{~mm}$ posterior to the bregma, with $0.5 \mathrm{~mm}$ intervals between each, and four sagittal specimens were taken from 0.5 to $2.0 \mathrm{~mm}$ lateral to the midline, with $0.5 \mathrm{~mm}$ intervals. Specimens were fixed for $48 \mathrm{~h}$ in $10 \%$ formalin at room temperature, then blocked with paraffin and cut into $3-\mu \mathrm{m}$ sections, before final staining with $\mathrm{H} \& \mathrm{E}$, as per standard protocols (13).

\section{FG retrograde labeling}

In this experiment, 30 P10 C57/BL6J mice were randomly divided into three groups ( $\mathrm{n}=10$ mice/group) and injected with three doses of $3 \% \mathrm{FG}(0.3,0.6,1.0 \mu \mathrm{L} /$ injection site). Random numbers were generated using the standard $=$ RAND() function in Microsoft Excel. We selected a small sample size because FG labeling was evaluated in neonatal mice for the first time in the present study, and therefore, the initial intention was to gather basic evidence regarding the use of this method. Briefly, mice were anesthetized by intraperitoneal injection of ketamine $(20 \mathrm{mg} / \mathrm{kg})$ and xylazine $(3 \mathrm{mg} / \mathrm{kg})$ cocktail. The surgical area was disinfected with $10 \%$ povidone iodine solution followed by $70 \%$ alcohol. The skin along with the center line of the head was cut with micro scissors to expose the SC area, and then stereotaxic apparatus was used to accurately locate the injection site: $3.0 \mathrm{~mm}$ posterior to the bregma and $1.0 \mathrm{~mm}$ lateral to the midline. A $26 \mathrm{G}$ needle was used to penetrate the skull through the injection site, then replaced with a $30 \mathrm{G}$ microneedle to inject FG to a depth of $1.5 \mathrm{~mm}$. The needle remained in place for 2 min after injection to allow dye absorption. The wound was closed with a suture.

\section{Quantification of FG labeling efficiency}

Mice were killed with an overdose of ketamine/xylazine cocktail 3 days after labeling. Eyes were enucleated and fixed for $15 \mathrm{~min}$ with $4 \%$ paraformaldehyde, then the cornea and lens were removed using corneal scissors and toothed forceps. The neural retina was excised and flatmounted with four cuts, then placed on a microscope slide. Using a fluorescent microscope (Carl Zeiss AG, Oberkochen, Germany), images were obtained at $1 / 4,1 / 2$ and $3 / 4$ distance from the optic nerve on each retinal petal. FG 
A

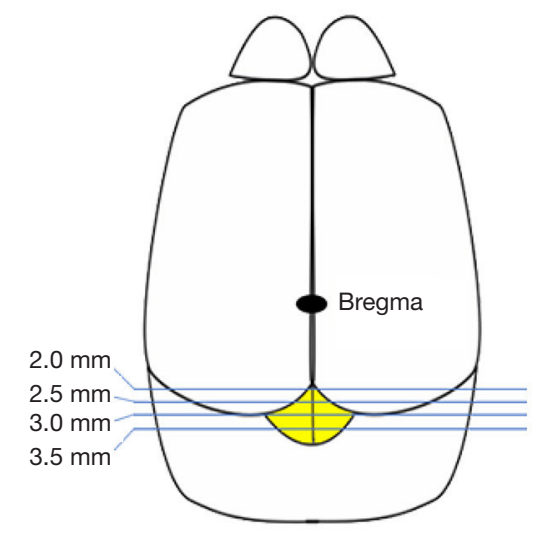

B
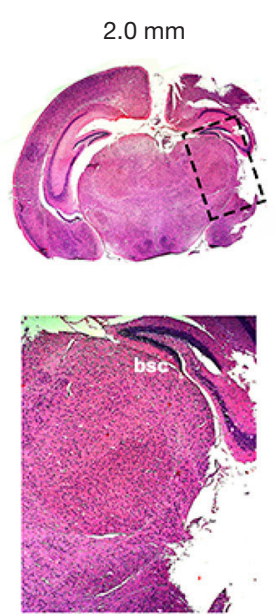

C
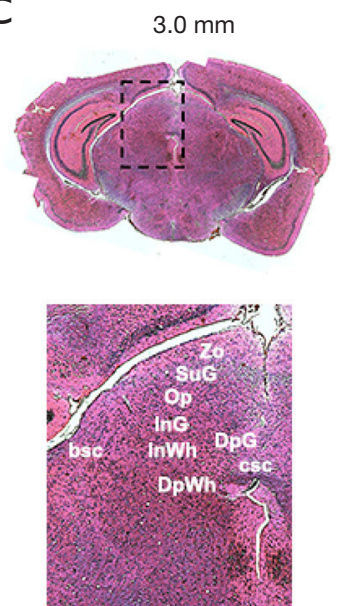
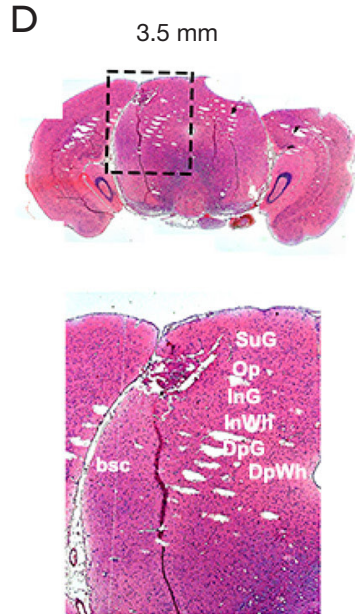

Figure 1 Localization of the superior colliculus (SC) in the coronal plane of postnatal 10 days (P10) mice. (A) Schematic of coronal plane sections across the SC area (yellow). (B,C,D) Hematoxylin and eosin-stained sections showing different SC structures at 2.0, 3.0 and $3.5 \mathrm{~mm}$ posterior to the bregma point (magnified details of these structures shown in 2nd row). Brachium of the SC (bsc); commissure of the SC (csc); deep gray layer of the SC (DpG); deep white layer of the SC (DpWh); intermediate gray layer of the SC (InG); intermediate white layer of the SC (InWh); optic nerve layer of the SC (Op); superficial gray layer of the SC (SuG); zonal layer of the SC (Zo).

intensity was quantified by Image $\mathrm{J}$ software (NIH). For the retina fluorescence assay, all fluorescence intensities in each quadrant of each group of retinas was normalized to mean levels in the temporal quadrant of the $0.3 \mu \mathrm{L}$ group. FGpositive cells were counted by two individuals, and the cell density was calculated as cell number/area $\left(\mathrm{mm}^{2}\right)$.

\section{Statistical analysis}

All data are expressed as mean \pm standard error of the mean. Significance was assessed with Student's $t$-test for two variable comparisons or by two-way ANOVA of multivariable comparisons using SPSS software (version 13.0; SPSS, Inc., Chicago, IL, USA). All data with $\mathrm{P}<0.05$ were defined as significantly different. Data was analyzed by an individual with no knowledge of the groups.

\section{Results}

\section{SC localization inP10 mice}

To localize the SC in the P10 mouse, the brain structure of C57/BL6J mice was compared with an atlas of the mouse brain (14). In the coronal plane, we found that the first SC structure, the brachium of the SC (bsc) was $2.0 \mathrm{~mm}$ posterior to the bregma point (Figure $1 A, B$ ), whereas it is
$2.54 \mathrm{~mm}$ posterior to the bregma point in the adult mouse brain. The section taken $3 \mathrm{~mm}$ posterior to the bregma point showed a similar structure to the $3.16 \mathrm{~mm}$ section of adult mouse brain and contained many more SC-related structures, including the bsc, commissure of the SC (csc), deep gray layer of the SC (DpG), deep white layer of the SC $(\mathrm{DpWh})$, intermediate gray layer of the SC (InG), intermediate white layer of the SC ( $\mathrm{InWh}$ ), optic nerve layer of the SC $(\mathrm{Op})$, superficial gray layer of the SC $(\mathrm{SuG})$ and the zonal layer of the SC (Zo) (Figure 1C). Fewer SC-related structures (bsc, DpG, DpWh, InG, InWh, Opand SuG) were found in the section taken $3.5 \mathrm{~mm}$ behind the bregma point (Figure 1D), comparable to $3.88 \mathrm{~mm}$ in the adult mouse. In the sagittal plane, we also found the SC-related structures varied according to the distance from the midline: the section taken $0.5 \mathrm{~mm}$ from the midline showed the bsc, DpG, DpWh, InG, InWh, Op, SuG and Zo (Figure 2A,B), the $1.0 \mathrm{~mm}$ section had fewer SC-related structures (bsc, $\mathrm{DpG}, \mathrm{InG}, \mathrm{InWh}, \mathrm{Op}, \mathrm{SuG}$ ) (Figure 2C), and the $2.0 \mathrm{~mm}$ section had only the bsc (Figure 2D), indicating the boundary of the SC in the sagittal planes. Corresponding brain sections of the adult mouse were $0.6,1.08$ and $2.28 \mathrm{~mm}$ lateral to the midline. These results revealed that the region, $2-3.5 \mathrm{~mm}$ posterior to the bregma point and $0.5-2.0 \mathrm{~mm}$ lateral to the midline, contained the major structures of the $\mathrm{SC}$ in the P10 wild-type mouse. 

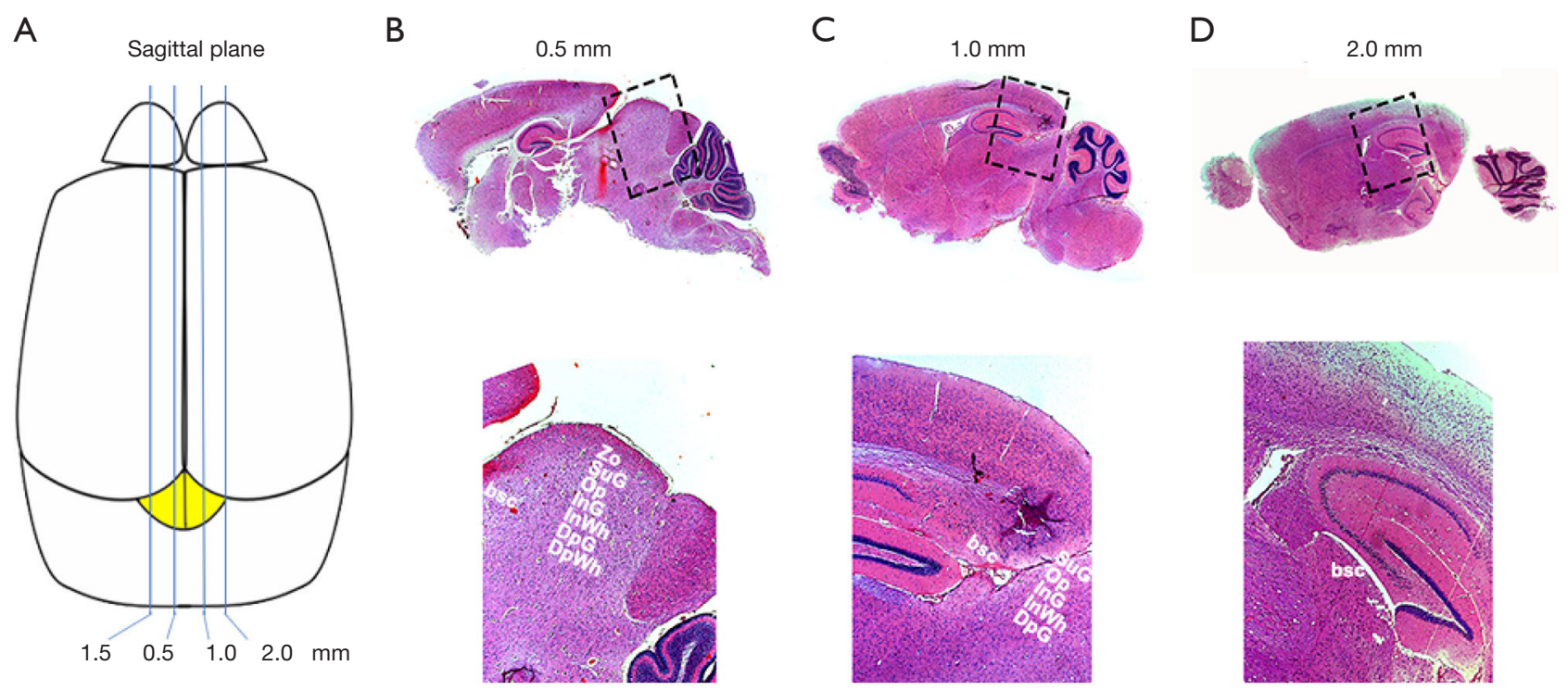

Figure 2 Localization of the superior colliculus (SC) in the sagittal plane of postnatal 10 days (P10) mice. (A) Schematic of sagittal plane sections across the SC area (yellow). (B,C,D) Hematoxylin and eosin-stained sections showing different SC structures at $0.5,1.0$ and 2.0 mm lateral to the midline (magnified details of these structures shown in 2nd row). Brachium of the SC (bsc); deep gray layer of the SC (DpG); deep white layer of the SC (DpWh); intermediate gray layer of the SC (InG); intermediate white layer of the SC (InWh); optic nerve layer of the SC (Op); superficial gray layer of the SC (SuG); zonal layer of the SC (Zo).

\section{RGC labeling efficiency}

Bright FG was detectable throughout the whole retinal flat-mount (Figure 3), with no obvious differences in relative fluorescence intensity among the three dose groups $(1.11 \pm 0.09$ in $0.3 \mu \mathrm{L}$ group, $1.36 \pm 0.09$ in $0.6 \mu \mathrm{L}$ group and $1.43 \pm 0.10$ in $1.0 \mu \mathrm{L}$ group, all fluorescence intensity normalized to mean level in the temporal quadrant of the $0.3 \mu \mathrm{L}$ group) (Figure $4 A, B$ ). Despite the similarity of fluorescence intensity among the groups, there was a significant difference in FGpositive cell density: $3,563.9 \pm 311.9$ cells $/ \mathrm{mm}^{2}$ in the $0.3 \mu \mathrm{L}$ group, which was significantly more than in the $0.6 \mu \mathrm{L}$ group $\left(1,718.6 \pm 177.1 \mathrm{cells} / \mathrm{mm}^{2}, \mathrm{P}<0.001\right)$ and $1.0 \mu \mathrm{L}$ group $\left(2,496.8 \pm 342.2\right.$ cells $\left./ \mathrm{mm}^{2}, \mathrm{P}<0.05\right)$; no significant difference was found between the 0.6 and $1.0 \mu \mathrm{L}$ groups (Figure 4C). Interestingly, we found a distinctive distribution of FG-positive RGCs across the retina: within $1 / 4$ distance from the optic nerve converged the highest density of RGCs $\left(3,946.9 \pm 253.0\right.$ cells $/ \mathrm{mm}^{2}$ in the $0.3 \mu \mathrm{L}$ group, $1,488.0 \pm 102.2$ cells $/ \mathrm{mm}^{2}$ in the $0.6 \mu \mathrm{L}$ group and $2,475.5 \pm 397.1 \mathrm{cells} / \mathrm{mm}^{2}$ in the $1.0 \mu \mathrm{L}$ group), with the density gradually reducing from $1 / 2$ to $3 / 4$ the distance from the optic nerve (Figures 3,4D). This distribution model was consistent in the three groups, though no statistical difference was found. As for dose-related effect on the distributions described, the low-dose group $(0.3 \mu \mathrm{L})$ still presented the highest FG-positive RGC density in all distributions (Figure 4D) compared with other two groups.

\section{Mice mortality}

As shown in Table 1 , in the 0.3 and $0.6 \mu \mathrm{L}$ groups, 1 out of 10 mice died $24 \mathrm{~h}$ after recovering from anesthesia. In the $1.0 \mu \mathrm{L}$ group, the mortality rate was $40 \%$. All deaths occurred between 24 and 48 h post-surgery.

\section{Discussion}

Since its introduction in 1986, FG has been widely used to label RGCs in different animals, but especially the mouse, as the most applicable model for studying RGC development, degeneration and regeneration (15-17). Most of the previous studies focused on the adult mouse, whose RGCs have matured thus making them less preferable for development studies (17) than neonatal mice. P10 is considered as one of the key points for RGCs fate orientation. However, it is hard to retrogradely track RGCs in P10 mice, given the lack of anatomic evidence of the SC region in neonatal mice (18). 


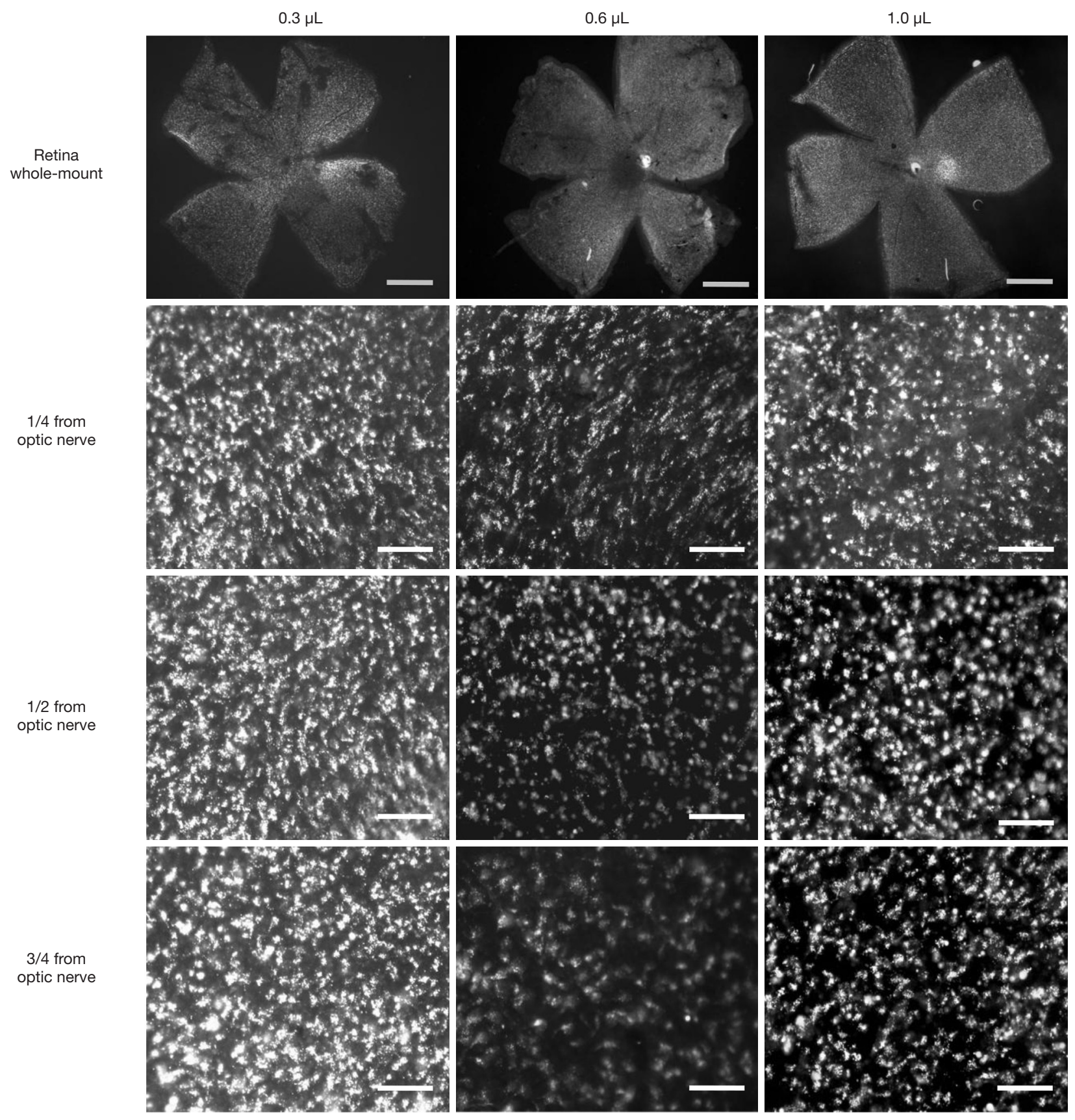

Figure 3 Comparison of fluorogold (FG) labeling efficiency in three dosing groups. Low-magnification fluorescence images of FG intensity in whole-retina flat-mounts (1st row). Scale bar: $500 \mu \mathrm{m}$. High-magnification fluorescence images of FG-positive cell density and distribution at $1 / 4$ distance from the optic nerve ( 2 nd row), $1 / 2$ distance from the optic nerve ( 3 rd row) and $3 / 4$ distance from the optic nerve (4th row). Scale bar: $50 \mu \mathrm{m}$.

By analyzing the anatomy of the P10 mice brain, we identified the appropriate injection site; that is, $2-3.5 \mathrm{~mm}$ posterior to the bregma point, and $0.5-2.0 \mathrm{~mm}$ lateral to the midline. The location is distinctive from the adult SC region, which ranges from $2.54-3.88 \mathrm{~mm}$ posterior to the bregma point to $0.6-2.28 \mathrm{~mm}$ lateral to the midline. 
A

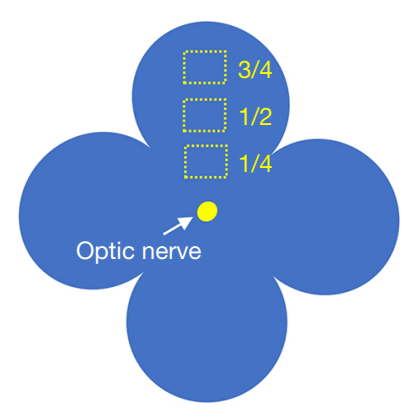

C

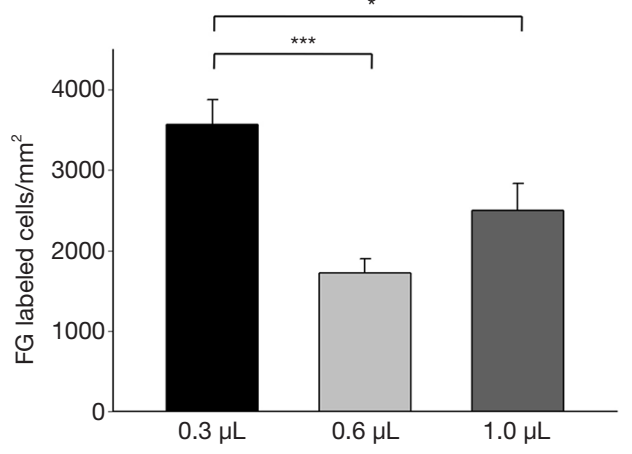

B

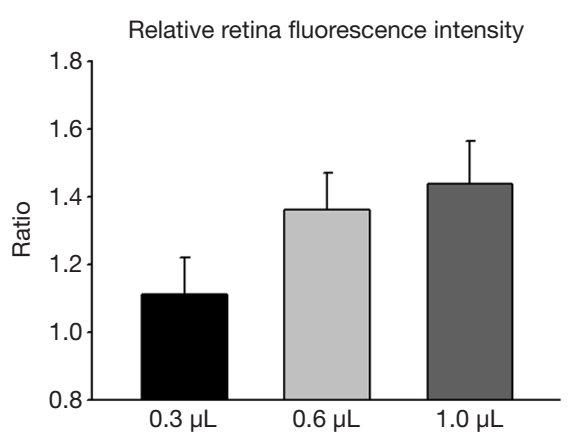

D

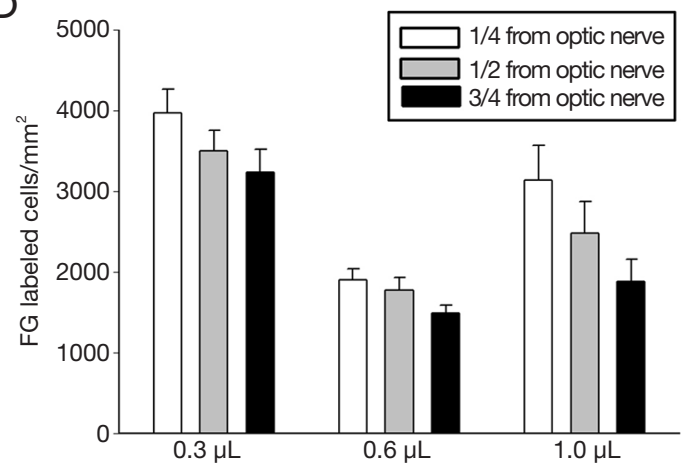

Figure 4 Imaging region, relative retinal fluorescence intensity and FG-labeled cell density in three dosing groups. (A) Schematic of imaging region at $1 / 4,1 / 2$ and $3 / 4$ distance from the optic nerve. (B) Quantification of relative retinal fluorescence intensity (all fluorescence intensity was normalized to mean level in the temporal quadrant of the $0.3 \mu \mathrm{L}$ group ( $\mathrm{n}=18$ in 0.3 and $0.6 \mu \mathrm{L}$ groups, $\mathrm{n}=12$ in $1.0 \mu \mathrm{L}$ group). (C) Statistical analysis of FG-positive RGC density in $0.3,0.6$ and $1.0 \mu \mathrm{L}$ groups ( $\mathrm{n}=216$ in 0.3 and $0.6 \mu \mathrm{L}$ groups, $\mathrm{n}=144$ in $1.0 \mu \mathrm{L}$ group). ${ }^{*} \mathrm{P}<0.05$, ${ }^{* * *} \mathrm{P}<0.001$ vs. $0.3 \mu \mathrm{L}$ group. (D) Comparison of FG-positive RGC density at different distribution sites ( $\mathrm{n}=72$ corresponding regions in 0.3 and $0.6 \mu \mathrm{L}$ groups, $\mathrm{n}=48$ in $1.0 \mu \mathrm{L}$ group). Data are presented as mean \pm standard error of the mean. FG, fluorogold; RGC, retinal ganglion cell.

Table 1 Mortality in the three fluorogold dosing groups of P10 mice

\begin{tabular}{lccc}
\hline Dose $(\mu \mathrm{L})$ & Injected mice $(\mathrm{n})$ & Dead mice $(\mathrm{n})$ & Mortality $(\%)$ \\
\hline 0.3 & 10 & 1 & 10 \\
0.6 & 10 & 1 & 10 \\
1.0 & 10 & 4 & 40 \\
\hline
\end{tabular}

P10, postnatal day 10 .

Successful RGC labeling has two critical elements: the efficiency of RGC labeling and the safety for recipients. Compared with other fluorescent dyes, FG has been demonstrated to be a good retrograde axonal tracer with the properties of intense fluorescence, extensive filling of dendrites, high resistance to fading and no diffusion from labeled cells $(11,15)$. In addition, distinctive from other dyes, it has wide duration of action and compatibility with all other tested neurohistochemical techniques (15). Another factor in effective and safe labeling is the dose of dye, apart from its natural characteristics. Individual dosing according to animal species is needed; for instance, 5.0 $\mu \mathrm{L} \mathrm{FG}$ is used for labeling adult rat RGCs (10), whereas $1.0 \mu \mathrm{L} \mathrm{FG}$ is preferable in the adult mouse (19). We compared RGC labeling efficiency in P10 mice by injecting three doses of FG, and found that $0.3 \mu \mathrm{L}$ was the most effective. Compared with the 0.6 and $1.0 \mu \mathrm{L}$ groups, the density of FG-positive RGCs in the $0.3 \mu \mathrm{L}$ group was $3,563.9 \pm 311.9$ cells $/ \mathrm{mm}^{2}$, comparable to that in adult mice $\left(3,230 \pm 157\right.$ cells $\left./ \mathrm{mm}^{2}\right)(19,20)$. Note that the number is slightly more than in adult mice, which is reasonable considering the elimination of incorrectly projected RGCs after P10 (3). The finding is interesting because highdose FG is theoretically supposed to label more RGCs than low-dose FG; conversely, we found that the lowest dose $(0.3 \mu \mathrm{L})$ could trace the highest number of RGCs. This may be attributed to low efflux from the pretectum when reducing the injected dye volume. Further studies regarding fluorescent molecular transportation in the 
visual pathway are needed to understand the exact mechanism of the different performance among the three doses.

Given the varying distribution of RGCs across the retina in rodents (21-24), we further evaluated if FG labeling could reveal the comparable RGCs distribution in P10 mice. RGC density of three regions ranging from the central to the peripheral retina was compared in the three FG dose groups. A gradual reduction in RGC density from the center to the periphery was observed in all three groups, and again, the $0.3 \mu \mathrm{L}$ group showed the highest RGC density from the center to the peripheral retina. This central-peripheral gradient pattern was consistent with that in the rodent retina.

Although injecting FG into the hippocampus, dorsal raphe nucleus, amygdala, and mediodorsal thalamic nucleus of rats has confirmed that it is non-neurotoxic (25-27), in comparison with adult mice, neonatal mice are more sensitive to chemicals (e.g., FG) and physical stress (e.g., trauma, intracranial pressure change). The mortality rate of the mice in this study is considered to be related to the FG dosage rather than the anesthesia for three reasons: (I). ketamine $(20 \mathrm{mg} / \mathrm{kg}) / \mathrm{xylazine}(3 \mathrm{mg} / \mathrm{kg})$ anesthesia is safe in neonatal mice (28); (II) all the neonatal mice recovered well from anesthesia within $1 \mathrm{~h}$ post-surgery without abnormal behaviors, whereas deaths of mice occurred $24 \mathrm{~h}$ postsurgery; (III) the high-dose FG group suffered significant higher mortality than the low-dose groups. The increased mortality in the high-dose FG group may have resulted from increased intracranial pressure caused by high volume of FG injected into the brain. It was also noticed that one mouse died in the $0.3 \mu \mathrm{L}$ group, so lower doses of FG $(0.1 \mu \mathrm{L}$, $0.2 \mu \mathrm{L}$ ) were adopted to reduce modality, but they showed much lower fluorescence intensity and density (data not shown) on retinal flat-mounts, indicating poor labeling effectiveness. Accordingly, $0.3 \mu \mathrm{L} \mathrm{FG}$ could be an appropriate dose to balance efficiency and safety.

In conclusion, the appropriate site for retrograde RGC labeling in $\mathrm{P} 10$ mice is the region located $2-3.5 \mathrm{~mm}$ posterior to the bregma point toward $0.5-2.0 \mathrm{~mm}$ lateral of the midline, and $0.3 \mu \mathrm{L} \mathrm{FG}$ is an appropriate dose for a safe and effective technique of tracing RGC development in the neonatal mouse.

\section{Acknowledgments}

Funding: This research was funded by Shenzhen San Ming Project (SZSM201812091) and Medical Scientific Research
Foundation of Guangdong Province of China (B2021216).

\section{Footnote}

Reporting Checklist: The authors have completed the ARRIVE reporting checklist. Available at http://dx.doi. org/10.21037/atm-21-2022

Data Sharing Statement: Available at http://dx.doi. org/10.21037/atm-21-2022

Conflicts of Interest: All authors have completed the ICMJE uniform disclosure form (available at http://dx.doi. org/10.21037/atm-21-2022). The authors have no conflicts of interest to declare.

Ethical Statement: The authors are accountable for all aspects of the work in ensuring that questions related to the accuracy or integrity of any part of the work are appropriately investigated and resolved. All animal studies were conducted according to the Association for Research in Vision and Ophthalmology (ARVO) Statement for the care and use of animals and approved by the Animal Ethics Committee of Zhongshan Ophthalmic Center, Sun Yat-sen University.

Open Access Statement: This is an Open Access article distributed in accordance with the Creative Commons Attribution-NonCommercial-NoDerivs 4.0 International License (CC BY-NC-ND 4.0), which permits the noncommercial replication and distribution of the article with the strict proviso that no changes or edits are made and the original work is properly cited (including links to both the formal publication through the relevant DOI and the license). See: https://creativecommons.org/licenses/by-nc-nd/4.0/.

\section{References}

1. Provis JM, Penfold PL. Cell death and the elimination of retinal axons during development. Prog Neurobiol1988;31:331-47.

2. Lee EJ, Gibo TL, Grzywacz NM. Dark-rearing-induced reduction of GABA and GAD and prevention of the effect by BDNF in the mouse retina. Eur J Neurosci 2006;24:2118-34.

3. O'Leary DD, Fawcett JW, Cowan WM. Topographic targeting errors in the retinocollicular projection and their elimination by selective ganglion cell death. J Neurosci 
1986;6:3692-705.

4. Zou SQ, Tian C, Du ST, et al. Retrograde labeling of retinal ganglion cells in adult zebrafish with fluorescent dyes. J Vis Exp 2014;3:87.

5. Varano GP, Parisi V, Adornetto A, et al. Post-ischemic treatment with azithromycin protects ganglion cells against retinal ischemia/reperfusion injury in the rat. Mol Vis 2017;23:911-21.

6. PanagisL, ZhaoX, Ge Y, et al. Gene expression changes in areas of focal loss of retinal ganglion cells in the retina of DBA/2J mice. Invest Ophthalmol Vis Sci 2010;51:2024-34.

7. Garcá M, Ruiz-Ederra J, Hernández-Barbáchano H, et al. Topography of pig retinal ganglion cells. J Comp Neurol 2005;486:361-72.

8. Cui Q, Lu Q, So KF, et al. CNTF, not other trophic factors, promotes axonal regeneration of axotomized retinal ganglion cells in adult hamsters. Invest Ophthalmol Vis Sci 1999;40:760-6.

9. Tsuda S, Tanaka Y, Kunikata H, et al. Real-time imaging of RGC death with a cell-impermeable nucleic acid dyeing compound after optic nerve crush in a murine model. Exp Eye Res 2016;146:179-88.

10. Nakano Y, Shimazawa M, Ojino K, et al. Toll-like receptor 4 inhibitor protects against retinal ganglion cell damage induced by optic nerve crush in mice. J Pharmacol Sci 2017;133:176-83.

11. Nadal-Nicolás FM, Jiménez-López M, Salinas-Navarro M, et al. Microglial dynamics after axotomy-induced retinal ganglion cell death. J Neuroinflammation 2017;14:218.

12. Stojic A, Fairless R, Beck SC, et al. Murine autoimmune optic neuritis is not phenotypically altered by the retinal degeneration 8 mutation. Invest Ophthalmol Vis Sci 2017;58:318-28.

13. Luna LG. Manual of histologic staining methods of the Armed Forces Institute of Pathology, 3rd ed. The Blakiston Division of McGraw-Hill, 1968:140-1.

14. Paxinos G, Franklin KBL. The Mouse Brain in Stereotaxic Coordinates, 4th Ed., Academic Press, 2012:156-8.

15. Wang JW, Liu YM, Zhao XF, et al. Gastrodin protects retinal ganglion cells through inhibiting microglialmediated neuroinflammation in an acute ocular hypertension model. Int J Ophthalmol 2017;10:1483-9.

16. $\mathrm{Hu} \mathrm{H}, \mathrm{Lu} W$, Zhang M, et al. Stimulation of the P2X7 receptor kills rat retinal ganglion cells in vivo. Exp Eye Res 2010;91:425-32.

17. Schmued LC. Development and application of novel histochemical tracers for localizing brain connectivity and pathology. Brain Res 2016;1645:31-5.

18. Sidman RL, Angevine JB, Pierce ET. Atlas of the mouse brain and spinal cord. Quarterly Review of Biology1971;35:422.

19. Wang X, Archibald ML, Stevens K, et al. Cyan fluorescent protein (CFP) expressing cells in the retina of Thy1CFP transgenic mice before and after optic nerve injury Neurosci Lett 2010;468:110-4.

20. Dräger UC, Olsen JF. Ganglion cell distribution in the retina of the mouse. Invest Ophthalmol Vis Sci 1981;20:285-93.

21. Jakobs TC, Libby RT, Ben Y, et al. Retinal ganglion cell degeneration is topological but not cell type specific in DBA/2J mice. J Cell Biol 2005;171:313-25.

22. Jeon CJ, Strettoi E, Masland RH. The major cell populations of the mouse retina. J Neurosci 1998;18:8936-46.

23. Salinas-Navarro M, Jiménez-López M, Valiente-Soriano FJ, et al. Retinal ganglion cell population in adult albino and pigmented mice: a computerized analysis of the entire population and its spatial distribution. Vision Res 2009;49:637-47.

24. Vereczki V, Köves K, Csáki A, et al. Distribution of hypothalamic, hippocampal and other limbic peptidergic neuronal cell bodies giving rise to retinopetal fibers: anterograde and retrograde tracing and neuropeptide immunohistochemical studies. Neuroscience 2006;140:1089-100.

25. McDonald AJ, Mascagni F. Neuronal localization of 5-HT type $2 \mathrm{~A}$ receptor immunoreactivity in the rat basolateral amygdala. Neuroscience 2007;146:306-20.

26. Lee HS, Eum YJ, Jo SM, et al. Projection patterns from the amygdaloid nuclear complex to subdivisions of the dorsal raphe nucleus in the rat. Brain Res 2007;1143:116-25.

27. Poulin JF, Chevalier B, Laforest S, et al. Enkephalinergic afferents of the centromedial amygdala in the rat. J Comp Neurol 2006;496:859-76.

28. Huang L, Hayes S, Yang G. Long-lasting behavioral effects in neonatal mice with multiple exposures to ketaminexylazine anesthesia. Neurotoxicol Teratol 2017;60:75-81.

(English Language Editor: K. Brown)

Cite this article as: $\mathrm{Hu} \mathrm{H}$, Liu Y, Li K, Fang M, Zou Y, Wang J, Ge J. Retrograde fluorogold labeling of retinal ganglion cells in neonatal mice. Ann Transl Med 2021;9(10):878 doi: 10.21037/atm-21-2022 